\title{
ANALISIS PENGARUH POLA PENGGUNAAN LAHAN TERHADAP HARGA LAHAN KORIDOR JALAN DARMO SURABAYA SEBAGAI KAWASAN PRESERVASI
}

\author{
Revin Caprityan**), Linda Dwi Rohmadiani*) dan Sugito*)
}

\begin{abstract}
Road Corridor Darmo Surabaya is one of the areas that have historical value in the past. Having old buildings are still original and its location in the middle of the city with such a high accessibility makes Darmo Road Corridor has its own economic value. Various land uses such as residential, office, trade, services, social, cultural and so on. Corridor which has the highest land prices in Surabaya related to land use, the price of land and buildings located along the corridor preservation Highway Darmo.

The result of the analysis is the pattern of land use and preservation of buildings located along the road corridor Darmo significantly affect the price of the land because of strong historical value with less kirasan prices there are about more than 25 million dollars for the building of colonial and getting down to about 10 million dollars for the building has undergone many reforms.
\end{abstract}

Keywords: Land Price, Preservation, Regresion Linier

\section{PENDAHULUAN}

Seiring dengan perkembangan zaman, pesatnya pertumbuhan suatu kota dan tingginya laju pertumbuhan penduduk membuat kebutuhan akan lahan menjadi semakin tinggi. Permintaan akan lahan dari tahun ke tahun terus meningkat sedangkan ketersediaan lahan yang ada pada umumnya relatif tetap. Harga lahan erat kaitannya dengan tata guna lahan, dan pada umummya berkaitan dengan lokasi. Pengaturan tata guna lahan di kota-kota saat ini memang menjadi suatu permasalahan yang sangat sulit dan rumit mengingat pertumbuhan dan perkembangan nilai lahan yang sedemikian tinggi serta kepadatan bangunan yang sangat tinggi pula. Selain itu terdapat nilai-nilai sosial dalam hubungan dengan penggunaan lahan, yang dapat berhubungan dengan kebiasaan, sikap moral, pantangan, pengaturan pemerintah, peninggalan kebudayaan, pola tradisional dan sebagainya (David, 1995).

Sebuah kota yang telah berkembang dengan pesat pasti memiliki kawasan dan situs-situs yang berharga dan menjadi saksi sejarah perkembangan kota tersebut dari sejak masa lampau. Biasanya bisa berupa satu tempat bersejarah, monumen, atau satu kawasan yang masih asli dan bangunanbangunannya masih sama dengan saat pembangunannya dulu. Hal tersebut merupakan aset sumber daya budaya yang memiliki berbagai nilai dan makna antara lain nilai dan makna informasi/ilmu pengetahuan ekonomi, estetika dan asosiasi/simbolik.
Didukung lokasi lahan yang strategis dan bentuk bangunan yang masih asli membuat nilai suatu lahan menjadi strategis dan tinggi (Darin, 1997).

Surabaya adalah kota metropolis dengan mobilitas penduduk sangat tinggi. Kota Surabaya saat ini tumbuh menjadi kota besar yang modern. Jumlah penduduk Kota Surabaya lebih dari tiga juta jiwa. Dari sekitar 290 km2 (29.000) hektar luas wilayah, Surabaya Sekitar 85 persen luas wilayah Surabaya atau 23.000 hektar digunakan untuk lokasi perumahan, ruko, dan bangunan lainnya, seperti apartemen, hotel, pusat perbelanjaan, gedung perkantoran, sekolah maupun universitas (property guite indeks 2013).

Kota Surabaya telah menjadi salah satu kota metropolis namun tetap memiliki berbagai bentuk peninggalan sejarah yang memiliki nilai historis yang tinggi salah satunya adalah bangunan-bangunan di beberapa bagian kota yang masih terjaga sampai saat ini, misalnya di Koridor Jalan Rajawali, kawasan Jalan Kembang Jepun dengan berbagai peninggalan kebudayaan kolonial Belanda di Surabaya pada masa lampau, Kawasan Sunan Ampel dengan peninggalan Islam yang begitu kental juga kawasan preservasi koridor Jalan Raya Darmo yang bangunannya masih bergaya arsitektur kolonial Belanda.

**) Mahasiswa PWK

*) Dosen PWK \& Teknik Lingkungan Universitas PGRI Adi Buana Surabaya 


\begin{abstract}
Tahun 2013 harga lahan di kawasan preservasi koridor Jalan Darmo masih menempati urutan teratas pada harga lahannya yaitu mulai sekitar 20 juta rupiah $/ \mathrm{m}^{2}$ (property guideindeks 2013). Dengan harga lahan yang setinggi itu lahan di Koridor Jalan Darmo masih terus saja diminati oleh para investor yang ingin membuka usaha disana. Namun tentu saja karena koridor Jalan Darmo merupaka kawasan preservasi kota yang dilindungi, untuk menggunakan bangunanbangunannya harus mengikuti aturan pemerintah Kota Surabaya sendiri, salah satunya adalah tidak diperbolehkan untuk mengubah bentuk bangunan yang ada. Pemanfaatan lahan di Koridor Jalan Darmo yang dari tahun ke tahun lebih kearah perdagangan dan jasa membuat lahan-lahan yang masih jadi kepemilikan pribadi menggiurkan para investor untuk mendapatkan lahan disana. Kondisi bangunan yang masih asli dan terjaga, masih sangat layak untuk di tempati juga

kebutuhan akan lahan yang terus meningkat dan faktor-faktor apa saja yang menyebabkan hal itu terjadi. Penelitian Navastara(2007) lebih kearah kenaikan nilai lahan dan penggunaannya di kawasan skala besar, namun tidak membahas tentang hubungannya dengan kawasan preservasi. Terakhir pada penelitian Edi (2009) memaparkan masalah turunnya harga lahan di sekitar wilayah penelitian dikarenakan bencana lumpur lapindo yang mempengaruhi penurunan nilai lahannya.

Berdasarkan dari hasil-hasil penelitian terdahulu yang berhubungan dengan pola penggunaan lahan pada suatu wilayah banyak membahas tentang dinamika lahan yang berhubungan dengan banyak faktor memang menunjukan hubungan juga pengaruh, namun berbeda dengan pelelitian ini yang nantinya akan menyinggung tentang pengaruh pola penggunaan lahan terhadap harga lahan yang terjadi pada suatu koridor penelitian, maka dari itu penelitian ini belum pernah dilakukan sebelumnya.
\end{abstract} lokasi strategis di sepanjang koridor Jalan Raya Darmo membuat kawasan tersebut bukan hanya menjadi kawasan preservasi kota yang dilindungi, namun juga menjanjikan dalam hal tata guna lahannya yang menjadi penyebab tingginya harga lahan dan bangunan di sepanjang Koridor Jalan Raya Darmo, bahkan setiap tahun terus meningkat. Peningkatan harga lahan di Koridor Jalan Darmo sedikit banyak pasti berhubungan dengan pola penggunaan lahannya sebagai kawasan preservasi.

Penelitian ini memiliki masalah yang menjadi bahasan utamanya yaitu bagaimana bentuk pola penggunaan lahannya, klasifikasi harga lahan dan pengaruh keduanya terhadap bangunan preservasi di koridor penelitian.

Tujuan dari penelitian ini menjelaskan tentang pengaruh pola penggunaan lahan terhadap harga lahan koridor Jalan Darmo sebagai kawasan preservasi.

Manfaat yang diharapkan dari studi ini adalah memberikan kontribusi kepada Pemerintah kota Surabaya mengenai kebijakan penatagunaan lahan di sekitar koridor Jalan Darmo Surabaya.

Penelitian terdahulu, Teguh (2007) disebutkan berbagai faktor yang dapat mempengaruhi nilai tanah pada umumnya. Namun tidak membahas tentang masalah harga lahan dengan pola penggunaan lahannya. Selanjutnya pada penelitian Hasyim (1995) lebih membahas kearah

\section{METODE PENELITIAN}

Jenis penelitian ini adalah penelitian deskriptif-kuantitatif. Penelitian ini deskriptif adalah penelitian yang memaparkan, melaporkan sesuatu peristiwa. Pada penelitian ini menjelaskan secara deskriptif klasifikasi harga lahan yang terjadi koridor Jalan Darmo Surabaya. Serta secara deskriptif menjelaskan preferensi kepemilikan dan penggunaan lahan masyarakat. Dari hal tersebut secara diketahui pola pemanfaatan dan penggunaan lahannya serta kecenderungan tinggi-rendah harga lahannya. Sedangkan untuk penelitian kuantitatif merupakan penelitian yang akan menganalisis pengaruh antara pola penggunaan lahan dan harga lahan dengan menggunakan analisis statistik regresi linier berganda.

Variabel penelitian adalah hal atau faktor yang diteliti dan memiliki ukuran baik secara kuantitatif maupun kualitatif. Variabel dalam penelitian ini yang terdiri dari :

$\mathrm{Y}=$ Harga lahan

$\mathrm{X}_{1}=$ Pola penggunaan lahan

$\mathrm{X}_{2}=$ Bangunan preservasi

Dalam penelitian ini yang menjadi populasi adalah jumlah seluruh persil bangunan yang ada di sepanjang koridor Jalan Darmo Surabaya. Jumlah populasi dalam penelitian ini adalah 121 bagunan.

Metode analisis yang digunakan dalam penelitian ini adalah metode analisis 
deskriptif-kuantitatif yaitu analisis untuk mengelola dan menafsirkan data yang diperoleh. Sehingga dapat menggambarkan dinamika harga lahan yang sebenarnya terjadi pada objek penelitian. Metode analisis ini digunakan untuk mendiskripsikan sejauh mana pengaruh nilai lahan di kawasan penelitian Sedangkan metode diskriptifkuantitatif digunakan untuk mengetahui faktor-faktor yang berpengaruh dan preferensi kepemilikan dan penggunaan lahannya.

\section{Analisis Pola Penggunaan Lahan}

Analisis ini digunakan untuk mendeskripsikan pola penggunaan lahan di kawasan penelitian koridor Jalan Darmo Surabaya, dengan sub variabel :

1. Peruntukan lahan

2. Status kepemilikan

3. Aksesbilitas

4. Bangunan preservasi

\section{Analisis Klasifikasi Harga Lahan Menurut Peruntukan lahannya}

Analisis ini bertujuan untuk menggetahui kisaran nominal harga lahan di kawasan penelitian menurut peruntukan lahannya.

\section{Analisis Pengaruh Pola Penggunaan Lahan dan Bangunan Preservasi Terhadap Harga Lahan.}

Metode analisis data yang digunakan dalam penelitian mengenai analisis faktor-faktor yang mempengaruhi pemilihan lokasi terhadap kesuksesan usaha jasa adalah menggunakan Analisis Regresi Berganda. Analisis ini bertujuan untuk mengetahui seberapa besar pengaruh variable bebas terhadap variabel terikat yaitu kesuksesan usaha $(Y)$, bentuk matematisnya adalah sebagai berikut :

$$
\mathbf{y}=\mathbf{a}+\mathbf{b x}_{1}+\mathbf{b x}_{2}+\mathbf{e}
$$

Dimana :

$y=$ Harga Lahan

$\mathrm{X}_{1}=$ Pola penggunaan lahan

$\mathrm{x}_{2}=$ Bangunan preservasi

$a=$ Konstanta

$\mathrm{b}=$ Koefisien regresi dari variabel $\mathrm{x}$

$\mathrm{e}=$ variabel penggangu

\section{HASIL PENELITIAN}

1. Analisis Karakteristik Pola Penggunaan Lahan

\section{Peruntukan Lahan}

Masing-masing segmen Jalan Darmo sangat beragam. Keberagaman guna lahan tersebut dapat dilihat dari segmen I hingga segmen IV. Dimana untuk segmen IV mayoritas guna lahannya adalah untuk perdagangan dan jasa, dan semakin ke segmen I guna lahannya mayoritas adalah untuk permukiman. banyaknya guna lahan perdagangan dan jasa pada segmen IV adalah karena segmen ini paling dekat dengan kawasan Tunjungan, dimana Tunjungan merupakan pusat kegiatan Kota Surabaya. Untuk lebih jelasnya dapat dilihat pada gambar

\section{1}




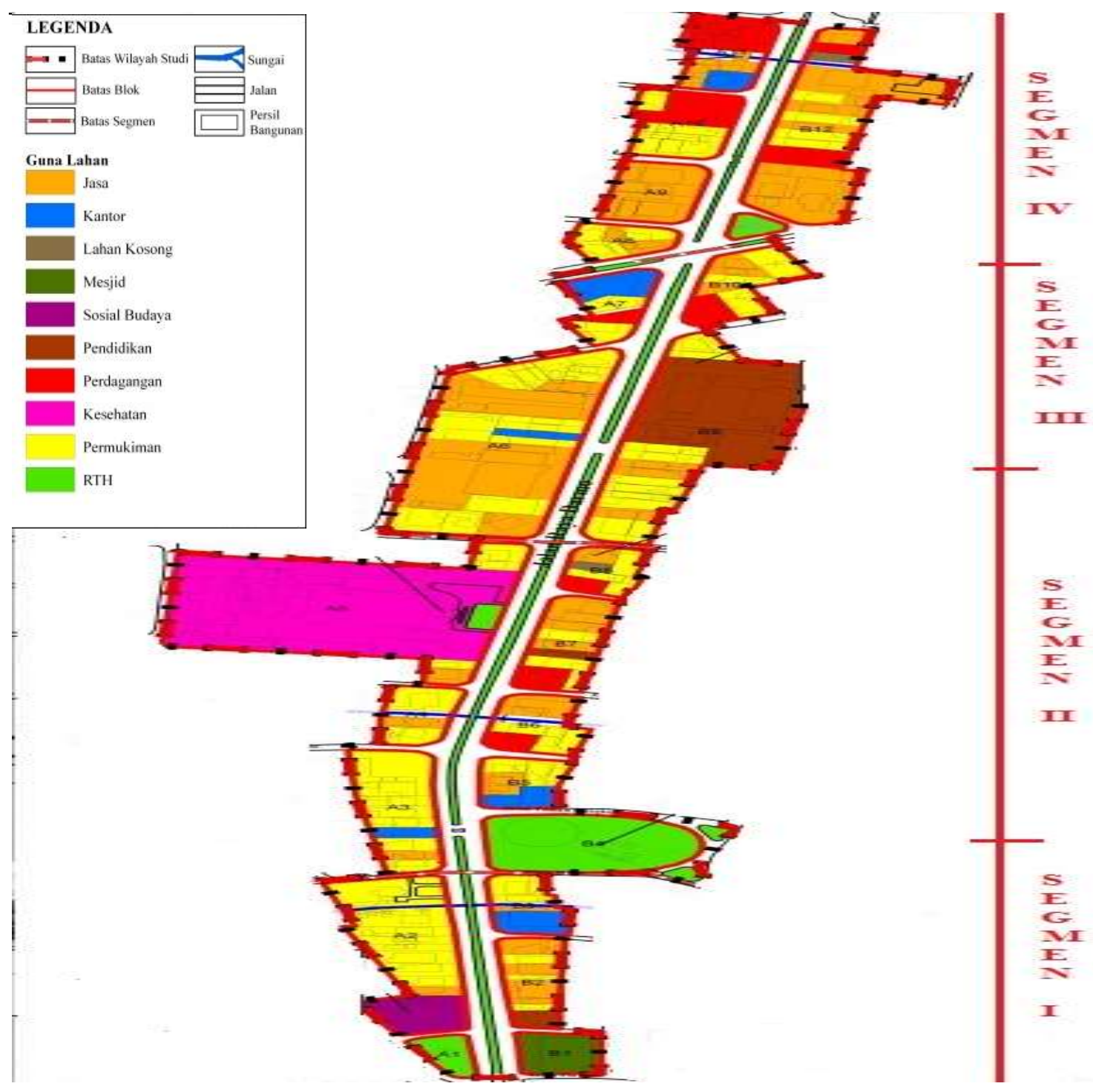

Gambar 1. Pola penggunaan Lahan Koridor Jalan Darmo

a. Guna lahan eksisting segmen 1 pada gambar 2 berupa guna lahan permukiman, kantor, jasa, RTH, peribadatan, dan sosial budaya.

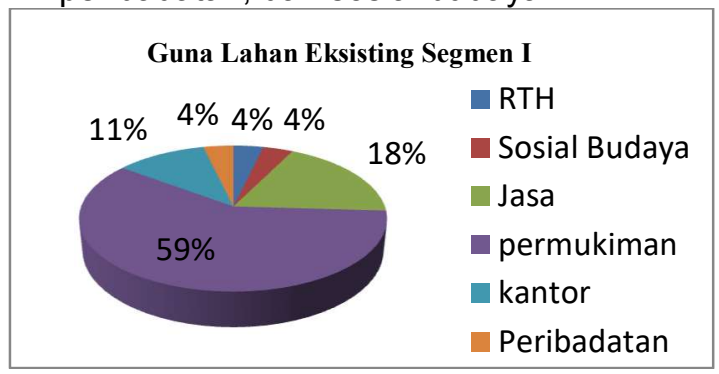

Gambar 2. Guna lahan segmen I

Gambar 2 pola penggunaan lahan segmen I menunjukkan bahwa sebayak $59 \%$ lahan di segmen 1 dimanfaatkan sebagai tempat hunian. Sedangkan lahan lainnya dimanfaatkan untuk kantor (11\%) dan jasa (18\%) sedangkan untuk sosial budaya, RTH, Peribadatan masing-masing $4 \%$.

b. Guna lahan eksisting segmen 2 berupa guna lahan permukiman, kantor, jasa, RTH, kesehatan, perdagangan dan pendidikan seperti pada gambar 3 . 


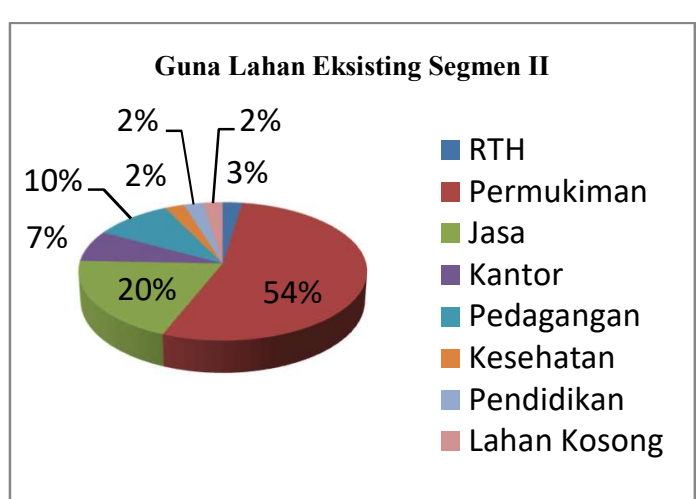

Gambar 3. Guna lahan segmen II

Gambar 3 segmen II mayoritas peruntukan lahannya adalah sebagai rumah tinggal (hunian) yaitu sebesar 54\%, sedangkan untuk jasa adalah sebanyak $20 \%$, perdagangan $10 \%, 7 \%$ untuk kantor. Paling sedikit peruntukan lahannya adalah untuk RSU, pendidikan, lahan kosong, dan RTH yang masing-masing sebanyak $2 \%$.

c. Guna lahan eksisting segmen 3 berupa guna lahan permukiman, kantor, jasa, perdagangan dan pendidikan seperti pada gambar 4.

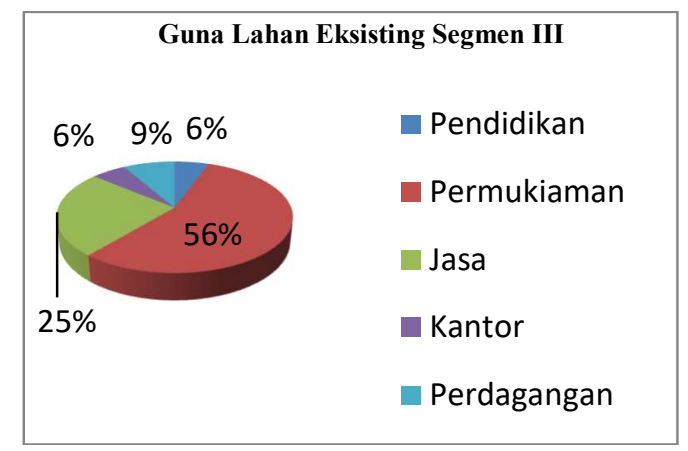

Gambar 4. Guna lahan segmen III

Gambar 4 tata guna lahan segmen III, menyebutkan bahwa mayoritas lahan di segmen 3 digunakan sebagai rumah tinggal yaitu sebanyak $56 \%$. Sedangkan lahan yang dimanfaatkan untuk jasa sebesar $25 \%$, perdagangan $9 \%$, pendidikan dan kantor masing-masing $6 \%$.

d. Guna lahan eksisting segmen 4 berupa guna lahan permukiman, kantor, jasa, RTH, kesehatan, perdagangan dan pendidikan seperti pada gambar 5 .

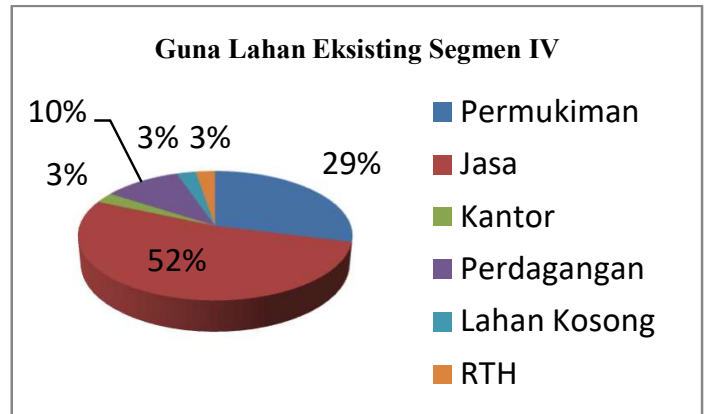

\section{Gambar 5. Guna lahan segmen IV}

Gambar 5 tata guna lahan segmen IV menyebutkan bahwa matoritas tata guna lahan di segmen IV dimanfaatkan untuk jasa yaitu sebesar $52 \%$. Sedangkan untuk rumah tinggal (permukiman) 29\%, perdagangan $10 \%$, dan sisanya $3 \%$ adalah untuk kantor, dan lahan kosong.

\section{Status Kepemilikan}

Koridor Jalan Darmo Surabaya yang sebagian besar diperuntukan untuk permukiman, perdagangan dan jasa masih didominasi untuk kepemilikan pribadi, antara lain seperti rumah tinggal privat, perkantoran dan perdagangan juga jasa. Sebagian besar para pemilik menyewakan per tahun untuk menjalankan bisnisnya. Para pemilik yang sesungguhnya pun dapat dikatakan enggan apabila akan menjual tanah mereka di Koridor Jalan Raya Darmo menggigat nilai investasinya yang tinggi, dan hanya menyewakan saja. Sertifikat hak milik (SHM) di Koridor Jalan darmo Surabaya rata-rata dimiliki oleh seluruh bangunan, sedangkan untuk beberapa bangunan lain yang guna lahannya untuk fasilitas umum seperti Rumah Sakit Darmo, Sekolah Santa Maria ataupun RTH status kepemilikannya adalah milik pemerintah.

\section{Aksesbilitas}

Jalan Raya Darmo yang menghubungkan wilayah Surabaya Selatan dan Surabaya Utara. merupakan jalan dengan hierarki arteri sekunder. Aksesibilitas pada jalan ini padat karena jumlah kendaraan yang melewati sangat tinggi. Pada hari sibuk terjadi kepadatan pada jam 06.00-07.00 karena mulainya aktivitas masyarakat yang berupa sekolah, bekerja, dan menuju pusat aktivitas lainnya dan pada jam 17.00-18-00 karena aktivitas menuju rumah dari tempat kerja.. Jenis kendaraan yang melintas di Koridor Jalan Raya Darmo sebagian besar adalah kendaraan pribadi berupa sepeda motor dan mobil. Jenis kendaraan yang melintasi jalan ini adalah 
bermotor, seperti sepeda motor, mobil, truck, pick up, bus, angkutan kota, taxi, dan mobil box, maupun non-motorise transportations, seperti sepeda. Di jalan ini kendaraan pada umumnya berkecepatan tinggi dikarenakan dimensi jalan yang lebar.

\section{Bangunan Preservasi}

Seluruh bangunan yang ada pada Koridor Jalan Raya Darmo merupakan bangunan yang bersifat permanen peninggalan kolonial dengan umur rata-rata diatas 60 tahun. Koridor Jalan Darmo yang memiliki keistimewaan dan karakteristik bangunan preservasi mempunyai bentuk dasar bangunan yang memiliki ciri khusus pada gaya arsitektur Kolonial Belanda dengan ciri-ciri sebagai berikut

- Atap perisai dengan kemiringan yang tajam yaitu $45^{\circ}$.
- Jenis pintu yang digunakan adalah pintu lipat bertangga-tangga.

- Jenis jendela adalah jendela sayap ganda dan sayap tunggal

Bentuk dasar bangunan tersebut dapat disimpulkan bahwa karakteristik bangunan di sepanjang koridor Jalan Raya Damro memiliki ciri khas yang sangat mencerminkan gaya arsitektur Kolonial Belanda. Orientasi bangunan merupakan arah dari tampak bukaan bangunan yang ditujukan pada potensi view yang optimal. Potensi view dapat berupa unsur alam, unsur fisik bangunan, atau ruang terbuka. Orientasi bangunan ini berfungsi untuk memberikan kesan teratur pada koridor jalan dan ruang atau bangunan yang ingin ditonjolkan seperti pada gambar 6 dibawah ini.
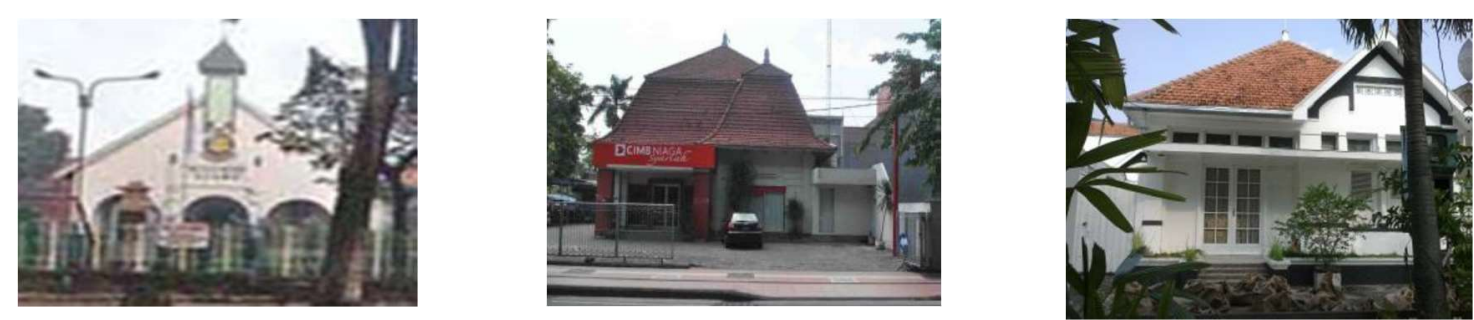

Gambar 6. Bentuk-bentuk bangunan preservasi Koridor Jalan Darmo

\section{Analisis Klasifikasi Harga Lahan}

Tabel 1. Analisa kisaran harga lahan pada tiap peuntukan

\begin{tabular}{ccl}
\hline No & $\begin{array}{c}\text { Peruntukan } \\
\text { Lahan }\end{array}$ & \multicolumn{1}{c}{ Kisaran harga } \\
\hline $\mathbf{1}$ & Sosial Budaya & $<25.000 .000$ \\
$\mathbf{2}$ & Permukiman & $15.000 .000-20.000 .000$ \\
$\mathbf{3}$ & Kantor & 10.000 .000 .15 .000 .000 \\
$\mathbf{4}$ & RTH & $<20.000 .000$ \\
$\mathbf{5}$ & Jasa & $9.500 .000 .-10.000$ \\
$\mathbf{6}$ & Lahan Kosong & 9.500 .000 \\
$\mathbf{7}$ & Pendidikan & $<25.000 .000$ \\
$\mathbf{8}$ & Kesehatan & $<25.000 .000$ \\
$\mathbf{9}$ & Perdagangan & $5.000 .000-7.000 .000$ \\
$\mathbf{1 0}$ & Peribadatan & 9.500 .000 \\
\hline \multicolumn{3}{c}{ Hasil Analisa 2014 }
\end{tabular}

Hasil analisis klasifikasi harga lahan pada tabel 1, peruntukan lahan yang digunakan sebagai sosial budaya yaitu ex Museum Empu Tantular, kesehatan yang peruntukan lahannya digunakan sebagai Rumah Sakit Darmo, RTH, sebuah peruntukan kantor yang digunakan sebagai kantor Graha Wismilak dan pendidikan yang digunakan sebagai sekolah Santa Maria dengan kisaran harga lahan sekitar Rp. 25.000.000- $/ \mathrm{m}^{2}$ menjadi peruntukan lahan dengan harga yang paling ringgi hal ini dikarenakan bentuk bangunan bergaya arsitekrur kolonial Belanda yang masih asli dan terjaga. Harga lahan yang paling tinggi setelahnya adalah peruntukan lahan yang digunakan sebagai permukiman atau rumah tinggal pribadi yang bentuk bangunannya pun masih asli dengan kisaran harga Rp.15.000.000.- Rp. 20.000.000-/m². Perbedaan harga lahan permukiman ini terjadi karena harga lahan di koridor Jalan Darmo semakin ke utara semakin rendah harganya, dan semakin ke selatan harganya pun semakin tinggi hal ini karena semakin ke utara.

Koridor Jalan Darmo mendekati kawasan Tunjungan yang merupakan pusat perdangangan dan jasa kota Surabaya. Memang pada umumnya harga lahan yang semakin mendekati pusat perdagangan dan jasa harganya akan semakin tinggi. Namun 
karena Koridor Jalan Darmo Surabaya termasuk kawasan preservasi kota yang dilindungi, maka yang mempengaruhi harga lahan adalah pola penggunaan lahan yang masih mengandung unsur preservasi

Selanjutnya peruntukan lahan sebagai perkantoran, peribadatan yang yang memiliki kisaran harga lahan Rp. 7.000 .000 - Rp.10.000.000 ada pada kategori sedang. Lalu untuk perdagangan merupakan pola penggunaan lahan yang

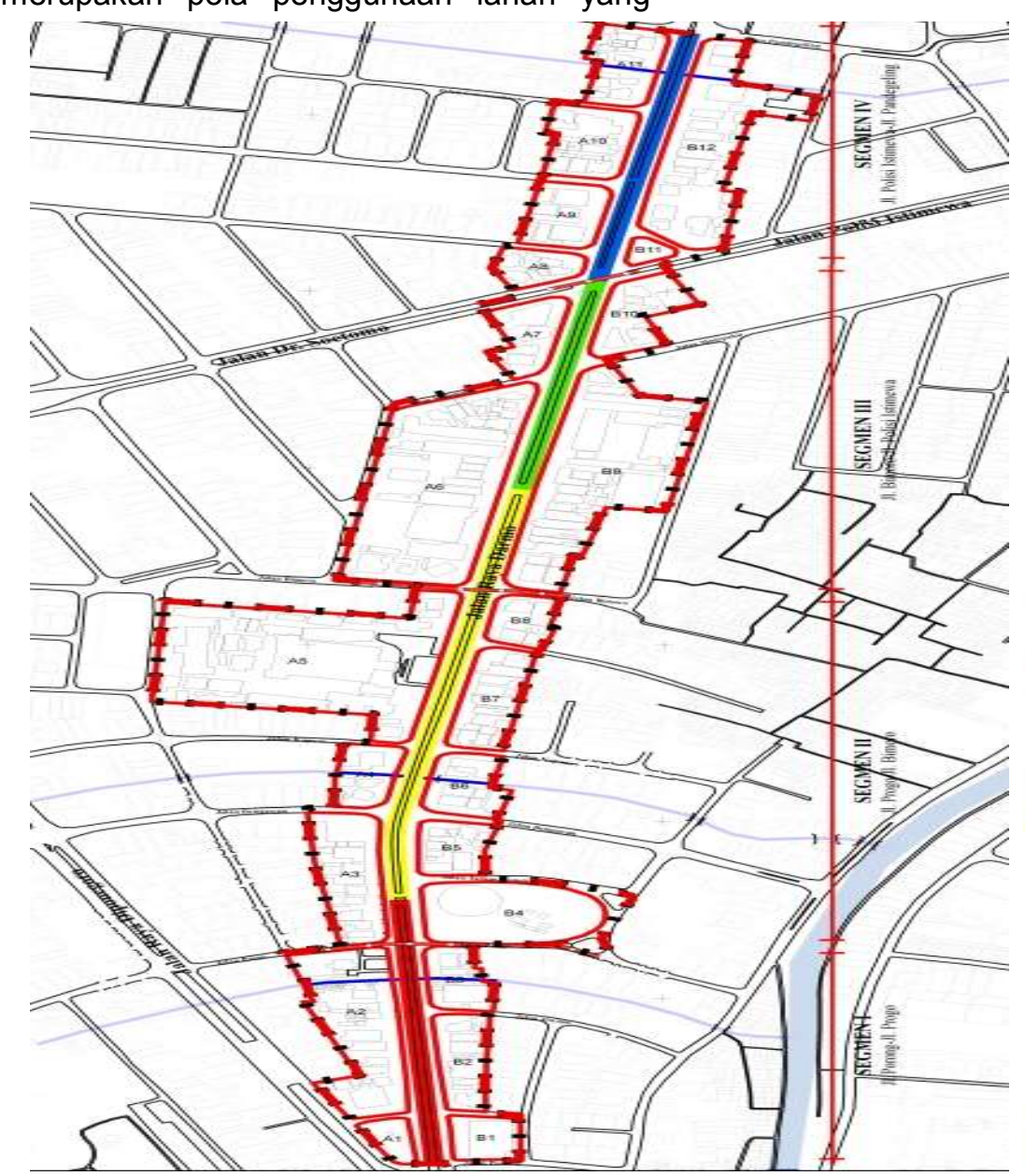

paling rendah harganya sekitar Rp. 9.000 .000 - Rp. $7.000 .000-/ \mathrm{m}^{2}$ hal ini disebabkan karena peruntukan lahan sebagai perdagangan banyak mengubah cirri khas asli sebuah bangunan. Bisa diambil contoh dari peruntukan lahan perdagangan yang digunakan sebagai rumah makan padang di segmen 4. Untuk lebih jelsnya pembagian klsifiksi harga lahan dapat dilihat pada gambar 7 .

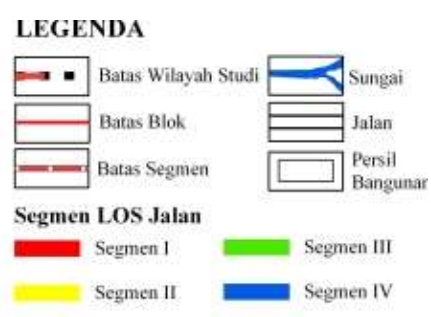

Segmen $1: 9,5$ jt- 25 jt

Segmen 2 : $\quad 7 \mathrm{jt}-20 \mathrm{jt}$

Segmen 3 : $\quad 7 \mathrm{jt}-20 \mathrm{jt}$

Segmen $4: \quad 7$ jt -18 jt

(Harga biasanya disesuaikan menurut penggunaan lahan dan pentuk bangunan)

Gambar 7. Peta klasifikasi harga lahan

\section{PEMBAHASAN}

Bahasan utama pada penelitian ini adalah untuk bagaimana pengaruh pola penggunaan terhadap harga lahannya yang menggunakan regresi linier berganda. Untuk mengetahui hubungan antara pola penggunaan lahan terhadap harga lahan maka dipergunakan analisis regresi linear dengan $\alpha=0,5$ (Convidence Interval). Hasil dari uji regresi tersebut diperoleh persamaan sebagai berikut :

$Y=4.292+0.736 \times 1+0.272 \times 2$
Analisa uji regresi yang telah dilakukan persamaan yang telah didapat bisa disimpulkan setiap bertambahnya satu tingkatan kategori penggunaan lahan maka harga lahan bertambah 0.736 juta dengan asumsi kategori preservasi konstan, dan setiap bertambahnya satu tingkatan kategori preservasi maka harga lahan bertambah 0.272 juta dengan asumsi kategori penggunaan lahan konstan.

Koefisien determenasi pada hasil analisa adalah $\mathrm{R}$ Square 0,589. Hal ini berarti bahwa pengaruh pola penggunaan 
lahan dan bangunan preservasi dapat dijelaskan oleh variabel independen yakni harga lahan sedangkan lainnya dijelaskan oleh sebab-sebab lain diluar model. Hasil pengujian uji $\mathrm{T}$ dan Uji $\mathrm{F}$ adalah sebagai berikut :

Uji T

T tabel alfa 0,05 dan $\mathrm{df}=121-1=120$

thitung $=6,126$. ttabel $=\alpha=0,05$

$\mathrm{T}$ tabel $<\mathrm{T}$ hitung ho ditolak $\mathrm{h} 1$ diterima

$T$ tabel $>T$ hitung ho diterima hi ditolak

Dari hasil pengujian dapat disimpulkan bahwa hipotesis yang berbunyi "Ada pengaruh antara pola penggunaan lahan dan bangunan preservasi terhadap harga lahan di Koridor jalan Darmo Surabaya" diterima secara signifikan.

Uji F

$\mathrm{F}$ hitung $=89,703 \mathrm{~F}$ tabel $=3,94$

Jumlah varian $-1=2-1=1$ Kasus $121-4=117$

$\mathrm{F}$ hitung $>\mathrm{F}$ tabel $\mathrm{H} 0$ ditolak $\mathrm{h} 1$ diterima

Dari hasil uji ANOVA atau uji $F$. didapatkan Fhitung sebesar 84,703 dengan signifikansi sebesar 0,000 . Karena probabilitas signifikansi tersebut kurang dari 0,1 maka model regresi dapat digunakan untuk memprediksi pengaruh pada harga lahan $(Y)$ atau dikatakan bahwa variabel pola penggunaan lahan $\left(x_{1}\right)$ dan bangunan preservasi $\left(\mathrm{x}_{2}\right)$ berpengaruh secara nyata terhadap variabel $\mathrm{Y}$.
KESIMPULAN
Koridor Jalan Darmo Surabaya memiliki berbagai macam pola penggunaan lahan diantaranya sebagai permukiman, sosial budaya, perdagangan, jasa, kantor, RTH, fasilitas umum seperti peribadatan, kesehatan dan pendidikan, juga lahan kosong memiliki peruntukan paling banyak adalah sebagai permukiman atau rumah tinggal, keaslian dan orisinilitas bangunan dan kawasan yang mempengaruhi harga lahannya.

Hasil analisis statistik yang telah dilakukan dapat simpulkan bahwa pola penggunaan lahan dan bangunan preservasi di Koridor Jalan Darmo mempengaruhi tinggi rendah harga lahannya. Semakin asli dan semakin sedikit mengalami perombakan bangunan maka semakin mahal harganya, dan yang terbanyak adalah peruntukan lahan sebagai permukiman (rumah tinggal).

\section{SARAN}

Mengingat harga lahan di Koridor Jalan darmo Surabaya yang begitu tinggi dikarenakan nilai historis dan penggunaan lahannya ada baiknya ababila pemerintah setempat tetap membuat kawasan tersebut tetap terjaga agar tetap mempertahankan citra kawasan dan menjaga nilai lahannya tetap bernilai ekonomis dan memiliki ke khasan tersendiri.

\section{DAFTAR PUSTAKA}

Darin-Drapkin, H. 1997. Land Policy and Urban Growth. Washington DC :

Navastara, A.M. 2007. Dinamika Harga Lahan dan Pengembangan Lahan Skala Besar Di PeriUrban (Kasus: Bumi Serpong Damai, Serpong-Tangerang) . ITB : Bandung

Teguh. 2007. Indikator Yang Mempengaruhi Nilai Tanah.

Hasyim. 1995. Pengaruh Nilai Lahan Terhadap Peningkatan Lahan di Perkotaan. ITB : Bandung Edi. 2009. Pengaruh lumpur lapindo porong terhadap nilai dan tata guna lahan dikabupaten Sidoarjo Rencana Tata Bangunan Dan lingkungan 2009. Surabaya

Property Guide Indeks, 2013, Nilai Lahan Terbaru ,http: //www.propertyguide.com/, tanggal akses 4 Januari 2014 